\title{
Biodegradation and Decolourization of Orange G by using Bacillus Sp. Isolated from Textile Effluents
}

\author{
Anamika Kumari $^{*}$, Arjita Punetha ${ }^{1}$, Alok Kumar ${ }^{2}$ and J. P. N. Rai ${ }^{1}$ \\ ${ }^{1}$ Department of Environmental Science, Govind Ballabh Pant University of Agriculture and \\ Technology, Pantnagar, Uttarakhand, India \\ ${ }^{2}$ Department of Mechanical Engineering, NIT, Patna, Bihar, India \\ *Corresponding author
}

\section{A B S T R A C T}

Keywords

Dye, Bacillus Species, Orange G. Textile effluents, Biodegradation

\section{Article Info}

\section{Accepted:}

12 December 2020 Available Online: 10 January 2021
In many commercial industries the azo dyes are the frequently used dyes. 25 bacterial isolates were taken from the textile waste, and form this 3 bacterial sample (AK 1, AK 2, AK 3) shows the best degradation capacity to degrade Orange G. By observing all the standard morphology and biochemical tests it was observed that these bacteria were the Bacillus Species, and it is found that isolate AK 3 showed the maximum decolourization i.e. $96 \%$ within 48 hours. The temperature at which the maximum degradation was observed is at $30^{\circ} \mathrm{c}$, the $\mathrm{pH}$ was set up to be normal and glucose was used as a carbon source and for the nitrogen source yeast extract was used. The enzymatic activity such as Azo Reductase, Tyrosinase, Lignin Peroxidase (LiP), Manganese Peroxidase (MnP) was observed as their role in biodegradation. This research paper is an analysis of illuminated collection of the benefit of enzymes for decolourization of azo dye and also their utilization for analysis of azo compounds present in waste water.

\section{Introduction}

Dyes play a very important role in almost every industry. Among the various dyes used in the industry Azo dyes are the most frequently and most widely used dye. Its structure is composed of the aromatic rings that are normally bound by two or more azo groups $(-\mathrm{N}=\mathrm{N}-)$. It is observed from the study that the annually world azo dye production is around 1 million tons (Pandey et al., 2007) and there are almost 2500 different structure azo dyes are used today (Kumar et. al., 2007). It has been reported that about $10-12 \%$ of dye which are used during the dying activity goes into waste water (Asad et al., 2007). These dyes are directly affecting the organism present in the water and cause various problems among them. (Ozturk \& Abdullah, 2006). Because of the complex aromatic molecular structure and synthetic origin these azo dyes are very difficult to degrade and form as a stable compound in the atmosphere.

Among these dyes reactive dyes form the covalent bonds as in binds to textile fibres mainly cotton by covalent bonds. (O' Mahony et al., 2002). For dying the cellulosic fibres 
the most effective method is reactive dyeing. The two main component of azo dye is the presence of azo bands and the Sulfonated group which we called the xenobiotic compound (Rieger et al., 2002). The treatment of this azo dye is difficult. But now a days there are various methods for treatment of these dyes. The biological method for the treatment of dye is most effective and ecofriendly as compared to other physicochemical method.

Various microbial stains are reported by the different researchers which are able to degrade the dye. (Rajaguru et al., 2000; Stolz, 2001). The breakage of azo dyes forms the aromatic amines which are known as mutagens. The bacterial degradation of dyes is much faster than the fungal degradation of textiledye stuffs (Pourbabee et al., 2005). Decolourization of dye solution by bacteria can bedue to biosorption or biodegradation. The bacterial activity is mostly biodegradation. However, in some cases, bacterialde colourization under aerobic conditions usually results in adsorption of dye stuffs on bacteriarather than their oxidation (Pourbabee et al., 2005). The adsorption of dye stuffs is rare in bacteria than in fungi as fungal cell wall is rich in chitin, in which hydroxyl and amino groups are present which makes it an efficient adsorbent for dye effluents. (Chen et al., 2003) found that dye biosorption or biodegradation can bejudged by the colour of cell mat. If thecell mat gets deeply coloured by the dye then the mechanism of dye removal is biosorption but if cell mat retains its original color then phenomenon of biodegradation can be attributed for dye removal.

The biodegradation of azo dyes involve 2 steps, first being the cleavage of azo dye and second being mineralization of intermediates. It is currently accepted that azo dye reduction is due to co-metabolic reaction, in which the biologically formed reducing equivalents can bechemically transferred to azo dyes.

Bacterial degradation of azo dyes is often mediated by azoreductase. Sulfonated azo dyes are not decolorized easily, as the permeation through the cell membrane is therate limiting step during bacterial reduction of azo dyes. Such decolourization occurs by an oxygen in sensitive azo reductase (Kodam et al., 2005).

This study had reported the species which are able to decolourize the Orange $G$ dye in aerobic condition.

\section{Materials and Methods}

\section{Sampling sites and Textile dyes used}

The sample was collected from the textile industry located in Gaya, Bihar, India. Orange $\mathrm{G}$ which is a type of azo dye which is used in this study. Stock solution was prepared by dissolving $100 \mathrm{ppm}$ dye sample in $100 \mathrm{ml}$ of distilled water.

\section{Isolation and Screening of Bacterial Strains Decolorizing Azo dye}

The effluent and sludge samples were serially diluted and spread over minimal agar medium containing 100 ppm of Orange G. $\mathrm{pH}$ was adjusted to 7.0 before autoclaving and incubated at $37^{\circ} \mathrm{C}$ for 5 days. Colonies surrounded by halo (decolorized) zones were picked and streaked on minimal agar medium containing azo dye. The pure cultures were maintained on dye-containing nutrient agar slants at $4^{\circ} \mathrm{C}$.

\section{Decolourization assay}

Loopful of bacterial culture was inoculated in Erlenmeyer flask containing $100 \mathrm{ml}$ of nutrient broth and incubated at $150 \mathrm{rpm}$ at 
$30^{\circ} \mathrm{C}$ for $24 \mathrm{~h}$. Then, $1 \mathrm{ml}$ of $24 \mathrm{~h}$ old culture of the bacterial isolates were inoculated in $100 \mathrm{ml}$ of nutrient broth containing $100 \mathrm{ppm}$ of Orange $\mathrm{G}$ and re-incubated at $30^{\circ} \mathrm{C}$ till complete decolourization occurs. Suitable control without any inoculum was also run along with experimental flasks. $1 \mathrm{ml}$ of sample was withdrawn every $24 \mathrm{~h}$ and centrifuged at 10,000 rpm for $15 \mathrm{~min}$.

Decolourization extent was determined by measuring the absorbance of the culture supernatant at $475 \mathrm{~nm}$ using UV-visible spectrophotometer, according to Hemapriya et al., (2010).

Decolourization efficiency $(\%)=$ Dye $(\mathrm{i})-$ Dye (r) / Dye (i) *100

Where,

Dye (i) refers to the initial dye concentration and Dye (r) refers to the residual dye concentration.

Decolourization experiments were performed in triplicates.

\section{Optimization of culture conditions for dye decolourization by Bacillus $s p$.}

\section{Effect of Temperature, $\mathrm{pH}$ and Dye Concentration}

The effect of temperature, $\mathrm{pH}$ and dyeconcentration on dye decolorizing ability of the isolate was studied. This was carried out by incubating the bacterial strains at different temperature $\left(25-45^{\circ} \mathrm{C}\right), \mathrm{pH}(5-9)$ and various dye concentrations (100-500 ppm).

\section{Effect of Carbon and Nitrogen source on Dye Decolourization}

To investigate the effect of various carbon and nitrogen sources, different carbon sources such as, glucose, lactose, and sucrose (1\%) and different nitrogen sources like yeast extract, beef extract, and peptone (1\%) wereadded as a supplement individually to Nutrient broth medium for decolourization of Orange G.

\section{Enzyme assays}

Assay was carried out in cuvettes with a total volume of $1 \mathrm{ml}$. One unit per enzyme activity was defined as the amount of enzyme that transformed $1 \mu \mathrm{mol}$ of substrate per minute (1 unit $=1 \mathrm{U})$. Preparation of CellFreeExtract The bacterial strain AK3 was inoculated in Nutrient Broth containing Azodye (Orange G) and incubated at $30{ }^{\circ} \mathrm{C}$. The cells were harvested by centrifugation at $7000 \mathrm{rpm}$ for 30 min in cooling centrifuge, wa shed with 50 $\mathrm{mM}$ phosphate buffer $(\mathrm{pH}$ 7.0) and resuspended in the same buffer. Then, the cells were disturbed and cell debris was removed by centrifugation at $4{ }^{\circ} \mathrm{C}$. The resultant supernatant was used as the source of crude protein / enzyme.

\section{Laccase activity}

Assay Laccase activity was determined using 2,2'- azino-di- (-3-ethylbenzo-thiazoline-6sulfonic acid) (ABTS) as the substrate. $5 \mu 1$ of $50 \mathrm{mM}$ citrate buffer $(\mathrm{pH} 4.0)$ was mixed with $430 \mu \mathrm{l}$ of distilled water and $20 \mu \mathrm{l}$ of laccase. The reaction was started by addition of $50 \mu 1$ of $6 \mathrm{mM}$ ABTS and increase in absorbance at $547 \mathrm{~nm}$ was monitored. The enzyme activity was calculated using anextinction coefficient of ABTS of $\varepsilon 436=36 \mathrm{~m} \mathrm{mol-1} \mathrm{cm-1} \mathrm{(Ander}$ and Messner, 1998).

\section{Tyrosinase assay}

Tyrosinase activity was determined in reaction mixture of $2 \mathrm{ml}$ containing $500 \mu \mathrm{l}$ of $0.01 \%$ catechol in $500 \mu \mathrm{l}$ of $0.1 \mathrm{M}$ phosphate buffer ( $\mathrm{pH} 7.4)$ and $1 \mathrm{ml}$ of cell free culture at $475 \mathrm{~nm}$ (Zhang and Flurkey, 1997). 


\section{Lignin peroxidase (LiP) assay}

LiP (Lignin Peroxidase) activity was determined by monitoring the formation of propanaldehyde at $475 \mathrm{~nm}$ in a reaction mixture of $2.5 \mathrm{ml}$ containing $500 \mu \mathrm{l}$ of 100 $\mathrm{mM}$ n-propanol, $500 \mu \mathrm{l}$ of $250 \mathrm{mM}$ tartaric acid, $500 \mu \mathrm{l}$ of $10 \mathrm{mM} \mathrm{H}_{2} \mathrm{O}_{2}$ and $1 \mathrm{ml}$ of cell free culture (Shanmugam et al., 1999) at 475 nm.

\section{MnP (Manganese Peroxidase) assay}

The reaction mixture contained $500 \mu 1$ of 50 $\mathrm{mM}$ sodium malonate buffer ( $\mathrm{pH} 4.5), 25 \mu \mathrm{l}$ of $20 \mathrm{mM} \mathrm{MnCl}_{2}$ solution, $415 \mu \mathrm{l}$ of distilled water and $50 \mu \mathrm{pf} \mathrm{MnP}$. The reaction was started by adding $20 \mu \mathrm{l}$ of $10 \mathrm{mM} \mathrm{H}_{2} \mathrm{O}_{2}$. The extinction of the solution was measured photometrically at the wavelength $475 \mathrm{~nm}$ $(\varepsilon 270=11.59$ mmol-1 cm-1) (Wariishi et al., 1992).

\section{Azo reductase assay}

Assay was carried out in cuvettes with a total volume of $1 \mathrm{ml}$ using colorimeter. The reaction mixture consists of $400 \mu 1$ of potassium phosphate buffer with $200 \mu$ of sample and $200 \mu \mathrm{l}$ of reactive dyes $(500$ $\mathrm{mg} / \mathrm{l})$. The reaction was started by addition of $200 \mu \mathrm{l}$ of NADH $(7 \mathrm{mg} / \mathrm{ml})$ and was monitored photometrically at $547 \mathrm{~nm}$. The linear decrease of absorption was used to calculate the azoreductase activity. One unit of azoreductase can be defined as the amount of enzyme required to decolorize $1 \mu \mathrm{mol}$ of Orange Gperminute.

\section{High Performance Liquid Chromatography (HPLC)}

This method was carried out according to (Sahasrabudhe et al., 2014) with some alteration. The removal of Orange $\mathrm{G}$ azo dye and a generation of decolourization products were monitored using an HPLC system equipped with an ODS C18 column (Shimadzu SPD 20A) with HPLC grade methanol $60 \%+40 \%$ deionized water as mobilephase at the flow rate of $0.6 \mathrm{~mL} / \mathrm{min}$ for $10 \mathrm{~min}$ at $265 \mathrm{~nm}$. A portion of the sample (10 microliters) was manually injected into the injector port, and then the metabolites were analysed using a dual absorbance UV detector.

\section{Results and Discussion}

Isolation, Screening and Identification of bacterial strains decolorizing textile dyes the results shown in Table. 1 revealed that 03 bacterial isolates, designated as $\mathrm{AK} 1$ to $\mathrm{AK} 3$ were found to becapable of decolorizing Orange G (Fig. 1).

Out of 03 isolates, AK3 was found to be the superior strain with the highest decolourization efficiency $(96.60 \%)$.

Morphological, cultural and biochemical characteristics of AK3 strains were tabulated in Table.2. On the basis of the above mentioned characteristic features and by the comparison with "Bergey's manual of Determinative Bacteriology", the isolate AK3 was identified as Bacillus sp. Strain AK3 (fig.2).

The extent of dye decolourization of Orange $\mathrm{G}$ by the bacterial isolates (AK1 to AK3) is shown in Fig. 3.

\section{Optimization of Dye Decolorizing Ability of} AK3 Isolate effect of Incubation time

Dye decolourization by Bacillus sp. Strain AK3 was found to be growth dependent, since considerable dye decolourization was noticed in the fermentation broth as soon as the bacterial strains entered the late exponential phase and the activity reached the maximum 
level in stationary phase after $72 \mathrm{~h}$ of incubation (Fig. 4).

\section{Effect of Temperature}

The influence of incubation temperature on the decolourization of Orange $\mathrm{G}$ by Bacillus $s p$. AK3 was studied at temperatures ranging from $25-45^{\circ} \mathrm{C}$. The color removal efficiency of the bacterial isolate (AK3) achieved highest levels $(95.02 \%)$ at $35^{\circ} \mathrm{C}$, after $72 \mathrm{~h}$ of incubation. However, incubation at temperatures below $30^{\circ} \mathrm{C}$ and above $40^{\circ} \mathrm{C}$ was found to be down regulating the decolourization percentage of the isolate (Fig. $5)$.

\section{Effect of pH}

Dye decolourization efficiency of Bacillus sp. AK3 against Orange $G$ was detected over a broad range of $\mathrm{pH}(5.0-9.0)$, with optimum decolourization of $(94.54 \%)$ being exhibited at neutral $\mathrm{pH}$ (7.0). At slightly alkaline $\mathrm{pH}$ (8.0), decolourization efficiency of the isolate was found to beeffective (82.54\%) (Fig. 6).

Table.1 Bacterial Strains Decolorizing

\begin{tabular}{|c|c|c|}
\hline S.No & Isolates & \% of Decolourization \\
\hline $\mathbf{1}$ & AK 1 & 87.66 \\
\hline $\mathbf{2}$ & AK2 & 80.64 \\
\hline $\mathbf{3}$ & AK3 & 96.60 \\
\hline
\end{tabular}

Table.2 Morphological, Cultural and Biochemical Characteristics of Bacillussp.

\begin{tabular}{|c|c|c|}
\hline S.No. & Testcharacteristics & Bacterial Isolate (AK3) \\
\hline I. & Morphological characteristics & \\
\hline 1. & Colony morphology & Round \\
\hline 2. & Cell morphology & Rod shape \\
\hline 3. & Gram reaction & Positive \\
\hline 4. & Motility & Motile \\
\hline II. & Physiological characteristics & \\
\hline 5. & Growth under aerobic condition & + \\
\hline 6. & Growth under anaerobic condition & + \\
\hline 7. & Growth in Liquid medium & + \\
\hline III. & Biochemical characteristics & \\
\hline 8. & Indole Test & - \\
\hline 9. & Methyl Red test & - \\
\hline 10. & Voges Proskauer's & + \\
\hline 11. & Citrate utilization & - \\
\hline 12. & Glucose & - \\
\hline 13. & Adonitol & - \\
\hline 14. & Arabinose & - \\
\hline 15. & Lactose & - \\
\hline 16. & Sorbitol & - \\
\hline 17. & Mannitol & - \\
\hline 18. & Rhamnose & - \\
\hline 19. & Sucrose & - \\
\hline
\end{tabular}


Fig.1 Orange G before and after decolorization in Nutrient Broth

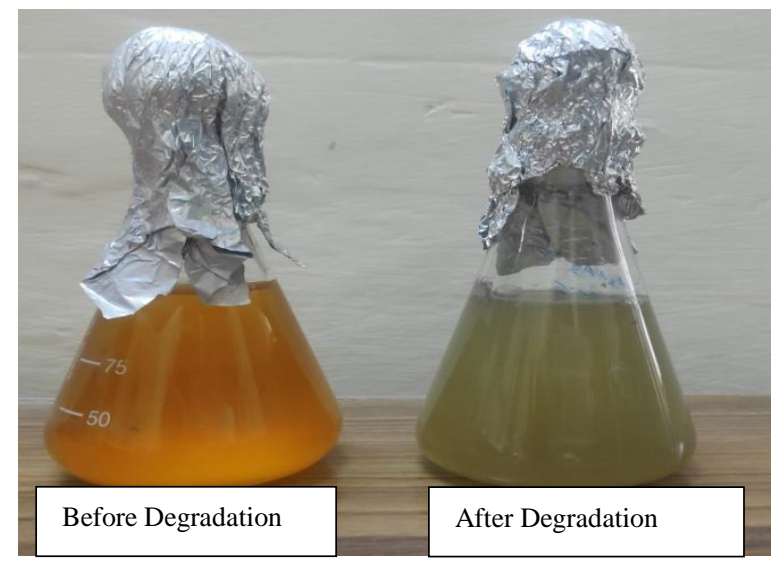

Fig.2 Biochemical Characteristics of Bacillus sp.

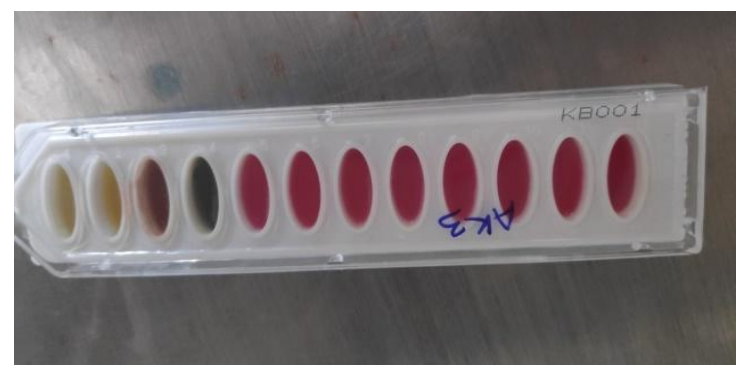

Fig.3 Decolourization efficiency of bacterial isolates towards Orange G

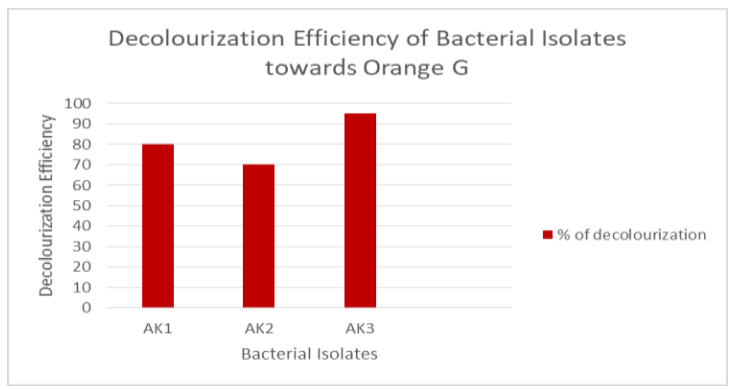

Fig.4 Effect of Incubation Time on Decolourization of Orange G by Bacillus sp. AK3

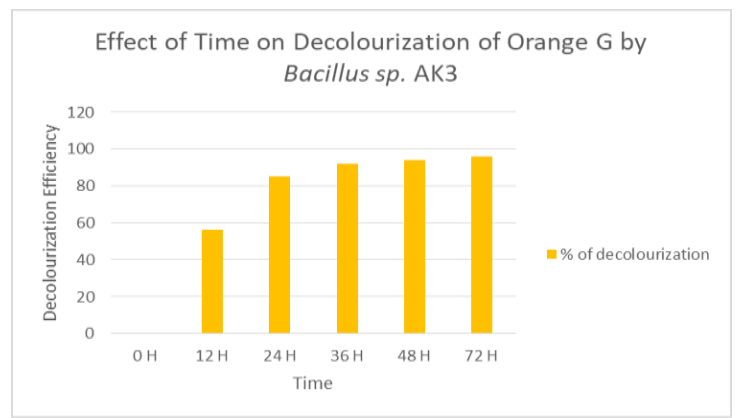


Fig.5 Effect of Temperature on Decolourization of Orange G by Bacillus sp. AK3

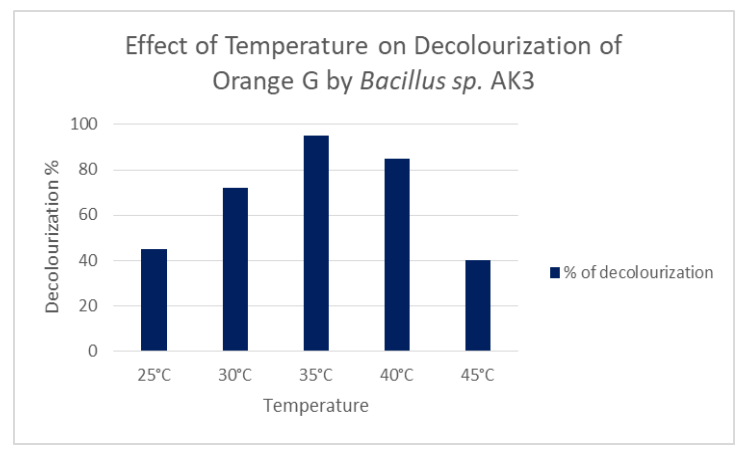

Fig.6 Effect of $\mathrm{pH}$ on Decolourization of Orange $\mathrm{G}$ by Bacillus sp. AK3

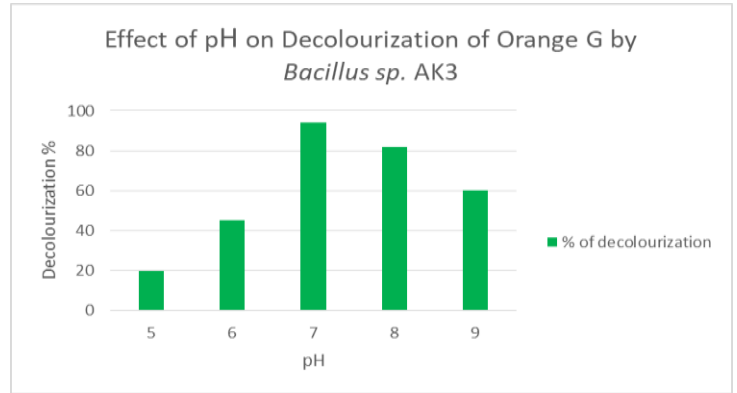

Fig.7 Effect of Dye Concentration on Decolourization of Orange G by Bacillus sp. AK3

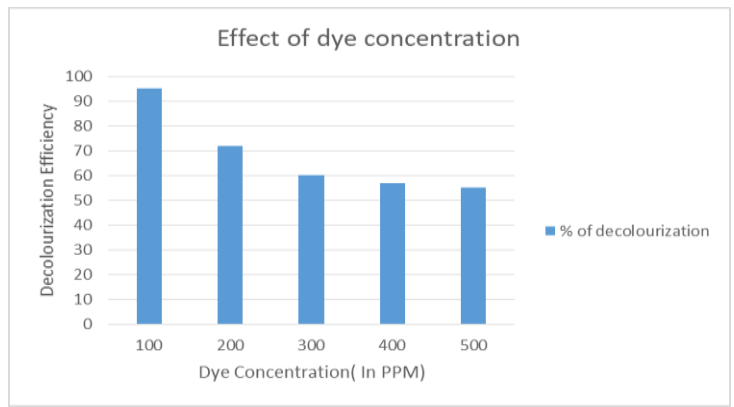

Fig.8 Effect of Carbon Sources on Decolourization of Orange G by Bacillus sp. AK3

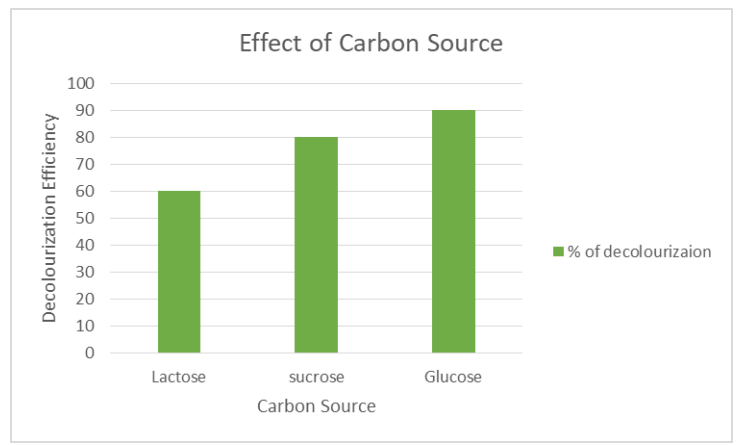


Fig.9 Effect of Nitrogen Sources on Decolourization of Orange G by Bacillus sp. AK3

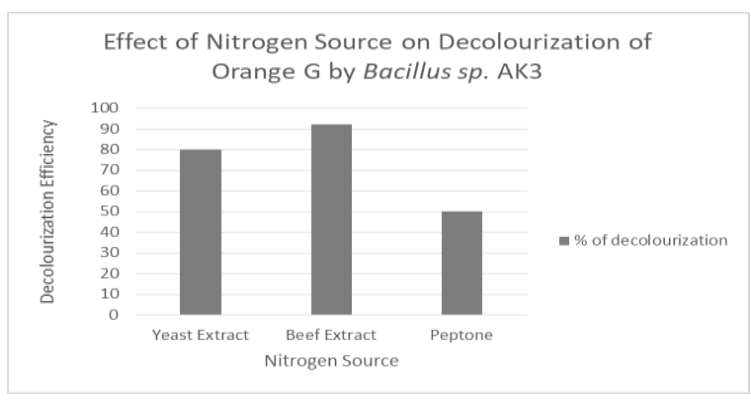

Fig.10 Extracellular Decolorizing Enzyme production by Bacillus sp. AK3

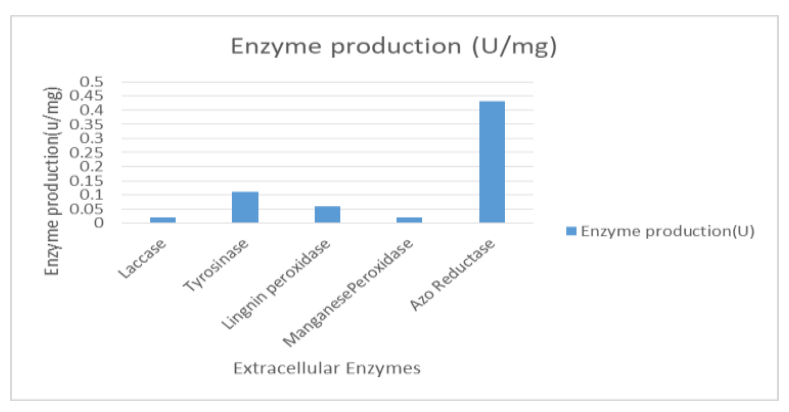

Fig.11 (A) HPLC profile of 100 PPM Orange G and (B) HPLC profile of Orange G treated by Bacillus sp., showing dye metabolites after decolourization
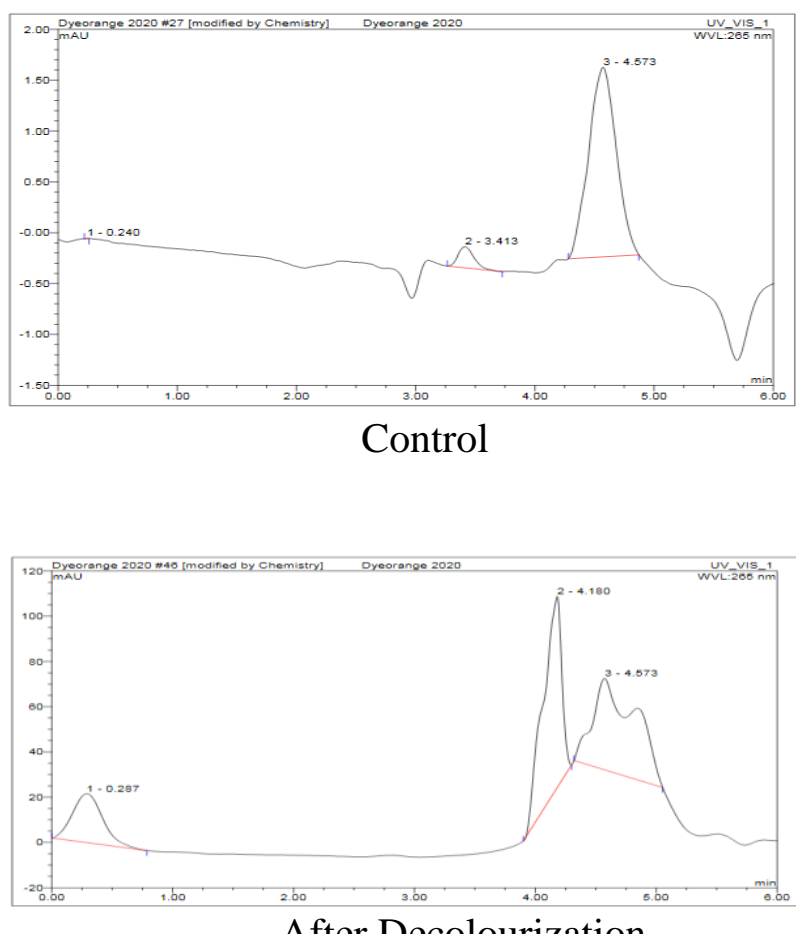

After Decolourization 


\section{Effect of Dye Concentration}

The results revealed that the decolourization rate of the isolates was optimized in the presence of initial dye concentration of 100 ppm (Fig. 7). As the dye concentration increased in the culture medium, a gradual and directly proportional decline in color removal was attained. At high concentration (500 ppm), Orange $\mathrm{G}$ greatly suppressed decolourization ability of Bacillus sp. AK3.

\section{Effect of Carbon and Nitrogen Sources}

The bacterial isolate AK3 was able to utilize most of the carbon sources tested, whereas glucose instigated maximum decolourization efficiency (90.93\%) (Fig. 8).Among the various nitrogen sources tested, yeast extract was found to be the superior source in maximizing decolorizing ability (92.90\%) (Fig. 9).

\section{Enzymatic assay for decolourization of Orange G}

The culture supernatant of AK3 cells that mediated the decolourization of Orange $G$ was screened for the presence of dye decolorizing enzymes such as Azoreductase, Laccase, Tyrosinase, Lignin Peroxidase, $\mathrm{MnP}($ Manganese peroxidase). Azoreductase was found to be the dominant enzyme $(0.43 \mathrm{U}$ $\mathrm{mg}^{-1}$ protein), whereas Laccase, Tyrosinase, Lignin peroxidase, MnP (Manganese Peroxidase were found to be secreted in verytrace amounts $(0.02,0.11,0.06,0.02 \mathrm{U}$ $\mathrm{mg}^{-1}$ protein respectively) (Fig. 10).

\section{High Performance Liquid Chromatography (HPLC)}

Fig.11 (A) HPLC profile of 100 PPM Orange $G$ and (B) HPLC profile of Orange $G$ treated by Bacillus sp., showing dye metabolites after decolourization
After 5 days of aerobic treatment process, HPLC analysis for biodegradation products was carried out. HPLC analysis of Orange G as a control showed a peak at the retention time of $4.573 \mathrm{~min}$. (Figure 11A), After the decolourization theBacillus sp.showed two metabolites peaks at the retention times of 4.180 and $4.573 \mathrm{~min}$. (Figure 11B). All samples showed the appearance of dye peak in the metabolites along with appearance of new peaks with different retention times which supported dye biotransformation to different metabolites.

In conclusion the environmental biotechnology is constantly enlarging its efforts in the biological analysis of coloured textile discharge, which is an environmental friendly and low-cost substitute to physicochemical decomposition method. The textile industries are chemical utilizing concerns, of which various dyes are of importance. Assembly of dye stuff creates environmental pollution and also health and aesthetic trouble. With the advent of civilization, the application of dye has become unavoidable and its release in the environment poses a severe problem. Therefore, an urgent need for technically practicable and cost-effective treatment method to be devised to overcome this problem is the need of hour. Microbial decolourization and degradation of various azo dyes have outstanding prospective to address various problem due to their environmental friendly and economical features. In addition to these bacteria have various other properties like growth rate is fast, hydraulic retention is high and therefore they are productive for the treatment of high strength waste waters. The literatures analysed in this research paper mainly focused on various experiments which have been carry out on decolourization of azo dye by the use of pure bacterial culture. In this study we have seen that, under aerobic state the subtractive division of these azo bonds 
form the toxic aromatic amines compound, so it is still very necessary to evaluate the efficient aromatic amine bacterial degraders. Since various other parameters also affect the performance of microorganisms and therefore, optimization of these is very necessary. To conquer the practicable process of dye decolourization, amplify knowledge of enzymatic study and comprehensive characterization of the intermediary and metabolites which are produced during the process of biodegradation using different scientific techniques. Further, to guarantee the safety of environment and to decolorize dye effluent, studies must be organize on the toxicity due to untreated effluent dye solution. Temperature variation had a significant effect on the decolourization of Orange $G$ by Bacillus sp. strain AK3. The rate of decolourization was found to be optimized at $35^{\circ} \mathrm{C}$ after $72 \mathrm{~h}$ of incubation. The rate of decolourization decreased with the decrease in temperature. This fact implies that the local temperature in the microenvironment of theeffluent samples has avery significant effect on the decolourization activity (Moosvi et al., 2005). Decolourization activity of Bacillus sp. strain AK3 was significantly suppressed at temperatures more than $40^{\circ} \mathrm{C}$, which might be due to the loss of cell viability or denaturation of the enzymes responsible for the decolourization at elevated temperatures. The most biologically feasible $\mathrm{pH}$ for the decolourization of Orange $\mathrm{G}$ byBacillus sp. strain AK3 was found to be7.0.

The foregoing results suggest the potential of utilizing Bacillus sp. strain AK3 to degrade textile effluent containing synthetic textile dyes via; appropriate bioreactor operation.

\section{References}

Ander, P. and Messner, K., 1998. Oxidation of1 - hydroxybenzotriazole by by laccase and lignin peroxidase.
Biotechnolo.Tech., 191- 5.

Asad, S., Amoozegar, M.A., Pourbabaee, A. A., Sarbolouki, M.N. and Dastgheib,S. M., 2007. Decolorization of textile azodyes by newly isolated halophilic and halotolerant bacteria. Bioresources Technology, 98: 2082-2088.

Chen KC, Wu JY, Liou DJ and Hwang S C J., 2003. Decolourization of the Textile Dyes by Newly Isolated Bacterial Strains.J. Biotechnol 101: 57-68

Hemapriya, J., Rajesh Kannan and Vijayanand, S., 2010. Bacterial decolorization of textile azo dye Direct Red - 28 under aerobic conditions. J. Pure Appl. Microbiol., 4(1): 309 - 314.

Kodam KM, SoojhawonI, Lokhande PD and GawaiK.R., 2005. Microbial Decolourization of Reactive Azo Dyes under Aerobic Conditions. World J.Microbiol. Biotechnol 21: 367-370

Moosvi, S., Kehaira, H. and Madamwar, D., 2005. Decolourization of textile dye Reactive Violet 5 by a newly isolated bacterial consortium RVM 11. World J Microbiol Biotechnol., 21: 667 - 672.

O'Mahony, T., Guibal, E. and Tobin, J.M., 2002. Reactive dye biosorption by Rhizopus arrhizus biomass. Enzyme Microb. Technol., 31: 456-463.

Ozturk, A. and Abdullah, M. 2006. Toxicological effect of indole and its azo dye derivatives on some microorganisms under aerobic conditions. Science of the Total Environment, 358: 137-142.

Pandey, A. Singh, P. and Lyengar, L. 2007. Bacterial decolourization and degradation of azo dyes. Int Biodeterior Biodegrad, 59: 73 - 84 .

Rajaguru, P., Kalaiselvi, K., Palanivel, M. and Subburam V. 2000. Biodegradation of azo dyes in a sequential anaerobicaerobic system, Appl. Microbiol. Biotechnol., 54: 268-273.

Pourbabaee, A. A., Malekzadeh, F., Sarbolouki, M.N. and Najafi, F., 2005. 
Biotechnology and Bio-engineering, Accepted, 8 August.

Rieger, P.G., Meier, H.M., Gerle, M., Vogt,U., Groth, T. and Knackmuss, H.J.,2002. Xenobiotics in the environment:present and future strategies to obviate the problem of biological persistence. J.Biotechnol., 94: 101-123.

Sahasrabudhe M M, Saratale RG, Saratale GD, Pathade GR., 2014. Decolorization and detoxification of sulfonated toxic diazo dye C.I. Direct Red 81 by Enterococcus faecalis YZ 66. J Environ Health Sci Eng 12(1): 151-163

Shanmugam, V., Kumari, M. and Yadav,K.D. 1999. n-proponol as substrate for assaying the lignin peroxidase activityof Phanerochaete chrysoporium. Indian Journal of Biochemistry andB iophyscis, 36: $39-43$.
Stolz, A. 2001. Basic and applied aspects inthe microbial degradation of azo dyes, Appl. Microbiol. Biotechnol., 56: 69-80.

Vijaykumar, M.H., Vaishampayan, P.A.,Shouche, Y.S. and Karegoudar, T.B.2007. Decolourization of naphthalene -containing sulfonated azo dyes by Kerstersia sp strain VKY1. Enzyme Microbial Technology, 40: 204211.

Wariishi, H., Valli, K. and Gold, M.H. 1992. Manganese (II) oxidation by manganeseperoxidase from the basidiomycetePhanerochaete. Kinetic mechanism androle of chelators, chrysoporium. J.BiolChem. 23: 688 95.

Zhang, X. and Flurkey, W.H. 1997. Phenoloxidases in portabellamushrooms. Journal of Food Science, 62: 97 - 100.

\section{How to cite this article:}

Anamika Kumari, Arjita Punetha, Alok Kumar and Rai, J. P. N. 2021. Biodegradation and Decolourization of Orange $\mathrm{G}$ by using Bacillus Sp. Isolated from Textile Effluents. Int.J.Curr.Microbiol.App.Sci. 10(01): 1046-1056. doi: https://doi.org/10.20546/ijcmas.2021.1001.127 